\title{
Yatırımcı Duyarlılığının Hisse Senedi Getirilerindeki Rolü ve Tüketici Güven Endeksiyle Ölçülmesi ${ }^{1}$
}

\begin{tabular}{c} 
Salim Sercan SARI ${ }^{2}$ \\
Şule Yüksel YİĞİTER ${ }^{3}$ \\
\hline Yayın Tarihi/ Published \\
25/01/2020
\end{tabular}

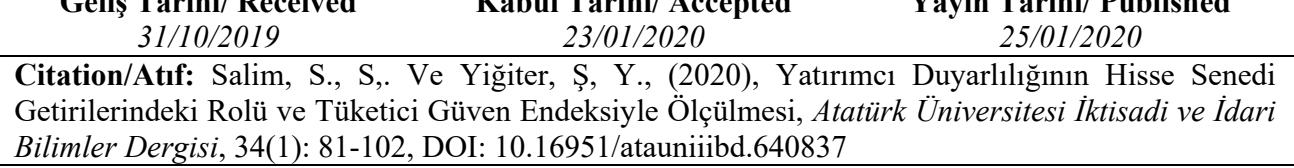

Öz: Türkiye gibi gelişmekte olan ekonomilerde hisse senedi getirilerinin tahmin edilmesi, finans çalışmalarında önemli araştırma konuları içerisinde bulunmaktadır. Ayrıca hisse senedi getirilerinin tahmin edilmesi yatırımcılar açısından da önemlidir. Bu çalışmada hisse senedi getirilerinin yatırıme duyarlılığı aracılığı ile tahmin edilmesi amaçlanmaktadır. Çalışmanın teorik kısmında ayrıntılı bir literatür çalışması yapılmıştır. Uygulama kısmında ise, tahmin için geliştirilen modellerde bağımsız değişken olarak yatırımcı duyarlılığını temsil eden Tüketici Güven Endeksi ve alt endeksleri kullanılmıştır. Bu kapsamda 5 değişkenle kurulan toplam 5 model kullanılarak destek vektör makineleri yöntemleri ile analiz yapılmıştır. Analizi yapılan tüm modellerde, 2007- 2018 yılları arasındaki aylık verilerden yararlanılmıştır. Değişkenlere ait toplanan 144 aylık verinin \%70' lik kısmı eğitim verisi olarak, \%30' luk kısmı ise matematiksel modellerin tahmin başarısını ölçmek için kullanılmıştır. Elde edilen bulgularda, destek vektör makinesi yöntemi ile yapılan tahminlerin başarılı sonuçlar verdiği görülmüştür.

Anahtar Kelimeler: Davranışsal Finans, Yatırımeı Duyarlılı̆̆ı, Tahmin, DVM.

\section{The Role of Investor Senstiment in Stock Returns and Measurement with Consumer Confidence Index}

Abstract: Estimating the returns of stocks in emerging economies such as Turkey is important research subjects in the finance studies. Estimates of stock returns are also important for investors. In this study, it is aimed to estimate stock returns through investor sentiment. Detailed literature study was conducted in the theoretical part of the study. In the application part, Consumer Confidence Index and sub-indices representing investor sentiment are used as independent variables in the models developed for estimation. In this context, totally 5 models with 5 variables were analyzed using support vector machines. Monthly data between 2007 and 2018 were used for all models analyzed. $70 \%$ of the 144 monthly data of the variables were used as educational data and 30\% of

${ }^{1} \mathrm{Bu}$ makale Dr. Öğr. Üyesi Şule Yüksel YİĞİTER danışmanlığında tamamlanan "Borsa İstanbul Hisse Senedi Getirilerinin Yatırımcı Duyarlılığı Aracılığıyla Tahmin Edilmesi" isimli doktora tezinden uyarlanmıştır.

${ }^{2}$ Arş. Gör., Erzincan Üniversitesi, İktisadi Ve İdari Bilimler Fakültesi, İşletme Bölümü, https://orcid.org/0000-0003-2607-5249

${ }^{3}$ Dr. Öğr. Üyesi, Erzincan Üniversitesi, İktisadi Ve İdari Bilimler Fakültesi, İşletme Bölümü, https://orcid.org/0000-0003-3230-5784 
Yatırımcı Duyarlılığının Hisse Senedi Getirilerindeki Rolü ve Tüketici Güven Endeksiyle Ölçülmesi

them were used to measure the prediction success of mathematical models. In the obtained results, it was seen that the estimations made by using indirect variables with the support vector machine method gave more successful results.

Keywords: Behavioral Finance, Investor Sentiment, Forecasting, SVM.

\section{Research Problem}

\section{EXTENDED ABSTRACT}

In order to determine the changes in investors\&\#39; expectations and have them make the right decisions, the effect of investor sentiment on stock returns has been tried to be forecasted for the markets in Turkey. The study aims to demonstrate the effect of investor sentiment on the behaviors of investors who invest in Borsa İstanbul and are not rational.

\section{Research Questions}

In this study, the relationship between investor sentiment and stock returns has been empirically estimated. In line with this, this study purports to give an answer to the question: Is it possible to predict the BIST 100 Index Return with the investor sentiment in the financial markets of Turkey?

\section{Literature Review}

National Thesis Center and international databases have been analyzed for theoretical and practical purposes. In the research, first of all, studies on investor sentiment have been taken into consideration. As a result of the research, it has been observed that there are some kind of suggestions that the Consumer Confidence Index and its sub-indices can be taken as an indicator of investor sentiment. Then, the success of the Consumer Confidence Index to estimate the BIST 100 Return Index have been determined based on the studies investigating the relationship between the Consumer Confidence Index and the BIST 100 Return Index.

\section{Methodology}

The data used in the study have been obtained from TÜIK and Borsa İstanbul databases. The period of January 2007 - December 2018 has been taken as sample and 144 observation values have been used on a monthly basis. In the analysis, the BIST 100 return Index has been included as a dependent variable. Independent variables used to measure investor sentiment and representing investor sentiment are the Consumer Confidence Index and the sub-indices of the Consumer Confidence Index. The Consumer Price Index (Inflation), which is one of the macroeconomic indicators, has been taken as a control variable to measure the forecast success of investor sentiment variables. The method that will support the theoretical part of the study is the Support Vector Machine (SVM). The prediction of the stock market has been modelled by the support vector machines method through representatives that measure investor sentiment. Firstly, training has been tested with 100 pieces of data and the model has been tested with the rest of 44 
pieces. In the analysis, each variable has been analyzed by BIST 100 Return Index and 5 models have been obtained. In order to measure the success of the prediction models, the Root Mean Square Error, Nash-Sutcliffe Model Efficiency Coefficient (NSE) and Average Numeric Error criteria have been discussed.

\section{Results and Conclusions}

Model success results have been interpreted with the help of mean error squares, NSE and parameters. It is noteworthy that the forecasting method, DVM performs successfully. When the analysis results have been analyzed, it has been seen that investor sentiment is successful in estimating stock returns. TÜIK-TGE can predict stock returns significantly. In general, it can be said that investor sentiment successfully predicts the BIST 100 Return Index although the estimation powers in the study are different. In Turkey, any study has not been encountered concerning the analysis of the sub-index of Consumer Confidence Index which is one of representatives of the investor sentiment in the estimated return. Hence, this study aims to contribute to the literature on this relatedtopic.

\section{I.Giriş}

Yatırımcı davranışları iktisadi sistemlerin esas unsurları arasında yer almaktadır. Yatırımcıların karar alma sırasında göstermiş olduğu eğilimler, bilimsel açıdan ve finansal piyasalarda dikkatle takip edilmektedir. Birçok kuramda yatırımcıların risk ve belirsizlik altında nasıl karar verdiği incelenmektedir. Teorik olarak birbiriyle farklılık gösteren söz konusu kuramlar genel olarak iki başlık altında toplanmaktadır. İlk başlık yatırımcıların rasyonel olduğunu öne süren geleneksel finans teorilerdir. İkincisi ise, karar vericilerin duyuşsal ve bilişsel önyargılarından etkilendiğini savunan davranışsal finans teorileridir. Davranışsal finans teorisyenleri, insanların yatırım alanlarında başarılı olabilmesi için bu önyargıları gerekli kılmanın önemli olduğuna inanmaktadırlar.

Beklenti Teorisi ile finans literatürüne giriş yapan davranışsal finans, menkul kıymetler üzerinde yatırımcı psikolojisinin etkili olabileceğini iddia etmektedir. Kahneman ve Tversky (1979)' nin çalışmasını takip eden ve finansal piyasalar üzerinde yatırımc1 psikolojisinin etkinliğini araştıran üç temel teori geliştirilmiştir. Bunlar zihinsel muhasebe teorisi, sürü davranışı teorisi ve çalışmaya konu olan yatırımcı duyarlılığ teorisidir.

Yatırımcı duyarlılığ1 modelinin dikkate alındığ Shleifer, Summers, Waldmann (1990) çalışmadır. Söz konusu modelde rasyonel yatırımcılarla birlikte gürültü işlemcileri de bulunmaktadır. Alım satım işlemlerinde rasyonel yatırımcılar bilgiye göre hareket ederken, gürültü işlemcileri bilgi yerine söylentilere göre hareket etmektedir. Bu durum piyasada işlem hacimlerinde artışa yol açabilmenin yanı sıra, yanlış fiyatlandırmalara da neden olabilmektedir.

Baker, Wurgler (2006) yatırımcı duyarlılığını temsil ettiğini savundukları birkaç değişken yardımıyla oluşturdukları yatırımcı duyarlıı̆̆ı endeksi ile yatırımcı 
duyarlılığını ölçmüş ve finansal piyasalara etkisini göstermişlerdir. Öncü niteliğinde olan bu çalışmada kullanılan değişkenler ve yöntem, sonraki dönemlerde yapılan yatırımcı duyarlılığıyla ilgili birçok çalışmaya kolaylık sağlamıştır.

Yatırımcıların gelecekteki kararları üzerinde etkisi olan yatırımcı duyarlılığı, davranışsal bir durum olduğundan doğrudan gözlemlenememektedir. Literatürde yatırımeı duyarlılığının finansal piyasalara etkisini inceleyen çalışmalarda çeşitli değişkenler kullanılmıştır. Bu temsili değişkenler yatırımcı duyarlılığını direkt ve dolaylı olarak ölçebilmektedir. Tüketici eğilim anketleri, güven endeksleri yatırımcı duyarlılığını direkt ölçen değişkenlere, işlem görme oranı, piyasa işlem hacimleri, hisse senedi ihraçlarının oranı ise yatırımcı duyarlılığını dolaylı olarak ölçen değişkenlere örnek verilebilir (Ergün, 2019).

Bu çalışmada, Türkiye için, 2007-2018 yılları aralığında yatırımcı duyarlılığı temsilcilerinden elde edilen bilgiler kullanılarak BİST 100 Getiri Endeksi tahmin edilmeye çalışılmıştır. Yatırımcı duyarlılığını ölçmek için, destek vektör makineleri yöntemleriyle TÜIKK Tüketici Güven Endeksi ve alt endeksleri ölçüt olarak kullanılmıştır. Analizlerde Statistica programı kullanılmıştır.

\section{Yatırımcı Duyarlılığı}

Duyarlılık, insanların herhangi bir yabancı nedenden ötürü, bir durum hakkında kendilerini aşırı derecede iyimser ya da kötümser hissetmesi olarak ifade edilmektedir. Psikoloji literatürünün büyük bir bölümü, insanların mevcut duygularının gelecekteki olaylara ilişkin kararlarını etkilediğini ortaya koymaktadır. Örneğin, sürekli üzücü gazete haberleri okuyan insanların, keyifli gazete haberleri okuyan insanlara nazaran çeşitli ölüm nedenleri (hastalık gibi) içeren haberlere dikkat ettikleri görülmektedir Bulgular, genel olarak olumlu duygulara sahip olan insanların iyimser karar verdiklerini ve seçimler yaptıklarını, buna karşıllk olumsuz duygulara sahip insanların ise daha kötümser tercihlerde bulunduğunu göstermektedir (Antoniou vd., 2013: 2).

Tercihleri ve inançları normatif ekonomik modelden ziyade, psikolojik kanıtlara uyan yatırımcıları tanımlamak için bir dizi terim kullanılmıştır. Bayes rasyonalitesinde ziyade sezgisel temelli inançlar bazen "yatırımcı duyarlılığı" olarak adlandırılmaktadır. Normatif modele göre davranışı rasyonel olmayan yatırımcılar, gürültü tüccarları olarak tanımlanmaktadır (Shleifer, 2000: 11-12).

Finansal piyasalarda yatırımcı duyarlılığı ilk kez 1986' da Black tarafindan ortaya atılmıştır. Temel finansal piyasa modelinde, söylenti bilgi ile zıt anlam taşımaktadır. İnsanlar bazen her zamanki gibi bilgi alışverişi yapmakta ve bu işlemlerden kâr elde etmeyi beklemektedir. Diğer taraftan, bazen bilgiye ulaşmış gibi davranarak söylentiyle ticaret yapmaktadır. Eğer yatırımcı söylenti ticareti ile kâr elde etme beklentisi içine girerse yanlış hareket etmiş olacaktır. Bununla birlikte söylenti ticaretine, likit piyasaların varlığg için gerek duyulmaktadır. Gürültü, finansal piyasalarda mümkün görünmesine rağmen piyasaları kusurlu hale getirebilmektedir. (Black, 1986: 529). 
Bu çalışmada değişken olarak kullanılan Tüketici Güven Endeksi, yatırımcı duyarlılığ 1 temsilcisi olarak sıklıkla kullanılmaktadır. ABD' de yapılan iki tüketici güven anketi, yatırımcı duyarlılığını temsil için dikkate alınmaktadır. Bunlardan biri Konferans Kurulu (the Index of Consumer Confidence) tarafindan toplanmakta, diğeri bağımsız olarak Michigan Üniversitesi Araştırma Merkezi (the Index of Consumer Sentiment) tarafından yürütülmektedir. Bu araştırmalarda, çok sayıda hane halkının kişisel mali durumu, ABD ekonomisine ilişkin beklentileri ve büyük hane halkı ürünlerini tüketme eğilimleri hakkında anket yapılmaktadır. The Index of Consumer Confidence, geçmiş durgunlukların tahmin edilmesinde faydalı olduğu kanitlanan Konferans Kurulu'nun önde gelen 10 ekonomik göstergesi listesine dahil edilmiştir. Çeşitli makaleler [Acemoglu ve Scott, (1994), Carroll, Fuhrer ve Wilcox (1994), Bram ve Ludvigson (1998), Ludvigson (2004)] tüketici güveninin gelecekteki hane halkı harcamalarını öngördüğünü tüketiciler, Michigan Üniversitesi Anket Araştırma Merkezi'ne göre faiz oranları, işsizlik, enflasyon, reel gayri safi yurtiçi hasıla (GSYH) ve konut satışlarındaki değişiklikleri dikkate almaktadır (Lemmon ve Portniaguina, 2006:1500).

Otoo (1999) yılındaki çalışmasında Michigan anketinden bireysel gözlemlerle yapılan önceki çalışmalarda çeşitli diğer faktörleri kontrol ettikten sonra dahi, duyarlılık ve gelirin pozitif ilişkili olduğunu bulmuştur. Ek olarak, Michigan ve Konferans Kurulu ölçütlerinin oluşturulma biçimi nedeniyle, daha elverişli bir mevcut finansal durum veya gelecekteki yüksek gelir beklentisi, duyarlılık meydana getirmektedir. Bu nedenle, mevcut refahı veya beklenen geliri arttıran faktörlerin de yatırımcı duyarlılı̆̆ını artırması beklenebilir. Bu noktadan hareketle, borsadaki davranışların yatırımcı duyarlıı̆̆ını etkileyebileceği iki genel yol vardır. Birincisi, borsadaki bir artış, yatırımcı duyarlılığını doğrudan artıracak şekilde beklenenden yüksek refahı yansıtabilmektedir. Duyarlılık ve hisse senedi fiyatlarını ilişkilendirebilmenin ikinci bir yolu, Poterba ve Samwick (1995) ve Morck vd. (1990) çalışmalarında görülmektedir. Bu modellerde, yükselen borsa, beklenen yüksek iş gücü gelirinin öncü göstergesi olarak hareket etmekte ve yatırım harcamalarını artırmaktadır. Borsa ve harcama arasındaki bu bağlantı, borsadaki artışın beklenen yaşam boyu serveti artırdığı ve bunun da daha yüksek harcamalara yol açtığını göstermektedir. Bu nedenle bu öncü gösterge hipotezi altında, yükselen bir borsanın duyarlılı̆̆ 1 arttırdığı işaret edilmektedir.

Yatırımc1 duyarlılı̆g , literatürde yatırımc1 iyimserliğinin potansiyel bir ölçüsü olarak da dikkat çekmektedir. Fisher ve Statman (2002) çalışmalarında 1987-2000 döneminde Amerikan Bireysel Yatırımcılar Birliği tarafından derlenen tüketici güven ölçütleri ile doğrudan yatırımcı duyarlılığı arasındaki pozitif korelasyonu ortaya koymaktadır. Tüketici güveninde irrasyonel bir unsurun varlığına dair kanıtlar da bulunmuş̧tur. Doms ve Morin (2004), ekonomik temelleri kontrol ettikten sonra, tüketici güven ölçütlerinin ekonomik içerikten ziyade ekonomik haber raporlarının tonuna ve hacmine cevap verdiğini tespit etmişlerdir (Lemmon ve Portniaguina, 2006:1500-1501). 
Türkiye' de de tüketicilerin davranışını ölçmek amacıyla Cnbc-e ve TÜİK/MB tarafindan oluşturulan tüketici güven endeksleri, aylık olarak belli sayıdaki hane halkına anketler aracılığıyla uygulanarak oluşturulmaktadır.

Bu çalışmada kullanılan TÜIK - TCMB Tüketici Güven Endeksi ise Türkiye İstatistik Kurumu ve Türkiye Cumhuriyet Merkez Bankası tarafindan birlikte gerçekleştirilen Tüketici Eğilim Anketleri aracılığıyla hesaplanmaktadır. Tüketicilerin kişisel mali durumları, tüketicilerin genel ekonomiye yönelik mevcut durum değerlendirmeleri, tüketicilerin gelecek dönem beklentileri, tüketicilerin yakın gelecekteki harcama ve tasarruf eğilimleri, Tüketici Eğilim Anketi ile aylık olarak ölçülmektedir (TÜİK, 2019).

Anket her ay 4884 haneye bilgisayar destekli yüz yüze görüşme yöntemiyle uygulanmaktadır. Hanede yaşayan 16 yaş ve üzeri fertler veri giriş programı yardımıyla tesadüfi olarak seçilerek anket sorularına cevap aranmaktadır. Sonrasında oluşturulan endeksler ise, Avrupa Birliği' nin yararlandığı denge metoduna göre işleme alınmaktadır. 0 ile 200 arasında değer alan endeksin 100' den büyük olması tüketici güveninde iyimserliği, küçük olması ise kötümserliği göstermektedir (TÜİK, 2019).

Tüketici güven endeksi hesaplanırken alt endekslerde dikkate alınmaktadır. Gelecek 12 aylık dönemi kapsayan hanenin maddi durum beklentisi, genel ekonomik durum beklentisi, işsiz sayısı beklentisi ve tasarruf etme ihtimali alt endeksleri 2012 yılından itibaren hesaplanmaktadır. 2004-2011 dönemi ise, çok değişkenli modele yönelik yaklaşımla geriye çekme modeli yardımıyla üretilerek kamuoyuna sunulmuştur.

\section{Yatırımcı Duyarlılığı Üzerine Yapılmış Çalışmalar}

Qui, ve Welch (2004) kapalı uçlu fon iskontosu ve tüketici güveni olmak üzere iki yatırımcı duyarlılığı ölçütünden faydalanmışlardır. Çalışma sadece tüketici güveninin değil, kapalı uçlu fon iskontosununda finansal piyasa fiyatlandırmasında güçlü bir rol oynadığını ortaya koymaktadır. Regresyon analizi sonucunda, UBS/Gallup yatırımcı duyarlılığı anketine göre tüketici güveninin yatırımcı duyarlılığı için uygun bir ölçüt olarak kullanılabileceği, kapalı uçlu fon iskontosunun uygun ise bir ölçüt olarak kullanılamayacağı ortaya çıkmıştır.

Charoenrook (2005) yatırımcı duyarlılığının hisse senedi getirileri üzerindeki etkilerine odaklanarak, duyarlılığının hisse senedi fiyatlarını etkileyip etkilemediğini incelemektedir. Tüketici duyarlılığı Michigan Tüketici Güven Endeksi'ne dayanmaktadır. Bulgular, yatırımcı duyarlılığının hisse senedi fiyatlarını etkilediğini ve bunların toplam hisse senedi piyasasını etkileyecek şekilde sistematik olarak ilişkilendirildiğini göstermektedir.

Kandır (2006) tüketici güven endeksinin İMKB mali sektör şirketlerinin hisse senedi getirileri üzerindeki etkisini regresyon analizi ile araştırmıştır. Şubat 2002-Haziran 2005 döneminde CNBC-E tüketici güven endeksindeki değişim ile kontrol değişkenleri (büyüklük primi, değer primi ve İMKB DİBS endeksi) bağımlı değişken olarak ele alınmıştır. Bulgularda diğer çalışmalarla tutarlılık gösterecek 
şekilde tüketici güven endeksinin mali sektör hisse senetlerinin çoğunluğu üzerinde önemli bir etken olduğu tespit edilmiştir.

Lemmon ve Portniaguina (2006) yatırımcı iyimserliğinin bir ölçütü olarak tüketici güvenini kullanıp, yatırımcı duyarlılığ arasındaki zaman serisi ilişkisini incelemişlerdir. Yatırımcı duyarlılığının ölçütleri olarak, iki anketten veri kullanılmıştır. Biri, Michigan Üniversitesi tüketici duyarlılığ1 araştırması, diğeri ise tüketici güveninin Konferans Kurulu araştırmasıdır. Regresyon analizi ile, duyarlılığın varlık fiyatlarında meydana getireceği davranışsal ve rasyonel etkiler incelenmiştir. Bulgular, güvenin duyarlık bileşeninin, piyasa betasında zaman serisi varyasyonuna izin verdikten sonra, işlem hacmi getirisinde zaman dizisi varyasyonunu tahmin ettiğini göstermiştir. Ayrıca tüketici güveninin duyarlılık bileşeninin kapalı uçlu fon indirimi ölçütüyle güçlü bir şekilde ilişkili olmadığı belirtilmiştir.

Olgaç ve Temizel (2008) İMKB'de yatırımcı duyarlılığ ile hisse senedi piyasaları arasındaki ilişkiyi araştırmayı amaçlamışlardır. İMKB-30 Endeksi ve TCMB-Tüketici Güven Endeksi (TÜGE)'nin aylık verilerine, uzun dönemli ilişkinin belirlenmesinde eşbütünleşme testi, kısa dönemli ilişkinin belirlenmesinde vektör hata düzeltme modeli uygulanmıştır. Sonuç olarak Tüketici Güven Endeksi'nin ve TÜFE'nin bir önceki dönem değerleri ile İMKB-30 endeksinin TÜGE üzerinde pozitif etkisi varken, DİBS'in negatif yönlü etkisi olduğu belirlenmiştir.

Schmeling (2009) bireysel yatırımcı duyarlılı̆̆ının bir temsilcisi olarak tüketici güveninin, 18 sanayileşmiş ülkede uluslararası olarak hisse senedi getirisini etkileyip etkilemediğini incelemiştir. Bu nedenle uluslararası duyarlılık-getiri ilişkisini araştırmak için, 18 sanayileşmiş ülke hisse senedi getirileri ve tüketici güveni verileri kullanılmıştır. Regresyon ve kesitsel analizle yapılan uygulama sonucu, duyarlılığın ülkeler genelinde ortalama getiri beklentileri için önemli bir tahmin unsuru olduğu görülmüsşür.

Fernandes vd. (2010) yatırımcı duyarlılığının bir temsilcisi olarak Ekonomik Duyarlılık Göstergesi' nin ve Tüketici Güveninin, Portekiz' de Eylül 1997 ile Nisan 2009 arasında gelecekteki toplam hisse senedi piyasas1 getirilerini ve endüstriyel endeks getirilerini tahmin edip etmediğini regresyon analiziyle araştırmışlardır. Sonuçlar, gürültü yatırımcıları davranışının etkisine dair teorik değerlendirmelerle tutarlı olarak, duyarlılığın 1 ile 12 aylık tahmin dönemleri için gelecekteki piyasa getirileri üzerinde olumsuz bir etkiye sahip olduğunu göstermiştir.

Akhtar vd. (2011) Westpac-Melbourne Uygulamalı Ekonomik ve Sosyal Araştırma Enstitüsü'nün tüketici duyarlılığının periyodik duyurulmasına yönelik olarak, Avustralya hisse senedi piyasasının tepkisini incelemişlerdir. Olumlu ve olumsuz duyarlılık haberlerinin hisse senedi fiyatlarını eşit olarak etkileyip etkilemediğini de ele almışlardır. 1992-2009 döneminde Westpac-Melbourne Uygulamalı Ekonomik ve Sosyal Araştırma Enstitüsü tarafından üretilen tüketici güven endeksi ile Avustralya Hisse Senetleri Endeksi verilerinden, panel veri analizi yöntemiyle faydalanılmıştır. Sonuçlara bakıldığında ilk olarak tüketici 
güven endeksinin değerli bilgi içeriğine sahip olduğu görülmüştür. İkinci olarak önceki aydan daha düşük bir tüketici güven endeksi açılandığında, Avustralya borsalarında önemli bir olumsuz haber günü etkisi yaşandığı ortaya çıkmıştır.

Bathia ve Bredin (2013) tüketici güven endeksi, yatırım sermaye fon akış1, kapalı uçlu fon indirimi ve lot altı satışların alışlara oranı dahil olmak üzere bir dizi yatırımcı duyarlılığı temsilcisinin değer stokları, büyüme stokları ve genel G7 piyasa getirileri üzerindeki etkilerini araştırmışlardır. Panel veri analiziyle Ocak 1995 - Aralık 2007 dönemi aylık verilerini kullanarak yaptıkları çalışmada yatırımcı duyarlılığı ve gelecekteki getiriler arasında negatif bir ilişki olduğunu ifade etmişlerdir.

Corredor vd. (2013) Avrupa' da ki öncü borsalardan Fransa, Almanya, İspanya ve İngiltere' de yatırımcı duyarlılığı etkisini analiz etmişlerdir. Hisse senedi özelliklerinden hareketle, gelecekteki hisse senedi getirileri üzerinde duyarlılığın etkisini açıklamayı amaçlamışlardır. Riske Maruz Değer (VAR) tekniği kullanılarak yapılan analizde ülkelere özgü faktörleri temsil eden değişken olarak işlem görme oranı, volatilite primi ve tüketici güven endeksi seçilmiştir. İlk iki değişken BW endeksindeki değişkenlerle aynı, üçüncü değişken ise halka arz verilerinin eksikliğini telafi etmek için kullanılan farklı bir değişkendir. Ülke piyasalarının ayrı ayrı analizi, yatırıme duyarlılığının, daha maliyetli ve arbitraj açısından riskli olan gelecekteki hisse senedi getirileri üzerinde önemli bir etkiye sahip olduğunu ortaya çıkarmıştır. Ulaşılan sonuçlarla, değerlendirilen ülkeler arasındaki farklılık saptanmış ve duyarlılık endeksi seçiminin önemi vurgulanmıştır. Duyarlılığın piyasalar arasında yoğunluğa bağlı olarak getiri üzerinde önemli bir etkiye sahip olduğu iddia edilmiştir.

Coakley vd. (2014) hem bireysel hem de kurumsal yatırımc1 duyarlılığ1 ölçütleri ile yedi hisse senedi endeks opsiyonunun risk-nötr çarpıklı̆̆ 1 arasındaki ilişkiyi incelemişlerdir. Çalışmada yatırımcı duyarlılığının hisse senedi endeksi opsiyon stillerini etkileyip etkilemediği sorusuna cevap aranmıştır. Bireysel duyarlılık ölçütü olarak Baker-Wurgler endeksi ve Michigan Üniversitesi Tüketici Güven Endeski, kurumsal yatırımcı duyarlılığı ölçütü olarak ise Yatırımcı İstihbaratı tarafından hesaplanan boğa yayılımı kullanılmıştır. Bulgularda duyarlılı̆̆ın, dört büyüme endeksi (Russell 1000 ve 2000 Büyüme endeksleri, S \& P SmallCap 600 Büyüme endeksi ve Nasdaq 100 endeksleri) üzerinde pozitif bir etki oluşturduğu ve üç değer endeksi seçeneğinden ikisi üzerinde olumsuz bir etki meydana getirdiği görülmüştür.

Ferrer vd. (2016), ABD ve 12 AB ülkesi için hisse senedi piyasası-tüketici güven ilişkisindeki zaman değişkenliğini vaka çalışmasıyla araştırmışlardır. Makro değişkenler olarak, $\mathrm{AB}$ ülkeleri için uyumlaştırılmış (OECD) Tüketici Fiyatları Endeksi ve ABD için tüm kalemler TÜFE Endeksi, mevsimsellikten arındırılmış aylık ortalama Sanayi Üretim Hacmi Endeksi, mevsimsellikten arındırılmış aylık ortalama işsizlik ve son olarak da 1 aylık bankalar arası faiz oranını almışlardır. Bulgular incelendiğinde Dotcom baloncuğu sona erdiğinde Avrupa'da tüketici güven endeksi-hisse senedi piyasası endeksi ilişkisinin azaldığı görülmüştür. 
Chau vd. (2016) ABD hisse senedi piyasasında yatırımc duyarlılığının yatırımcıların alım satım davranışını etkileyip etkilemediğini test etmişlerdir. İlk ölçüt Baker ve Wurgler (2006) tarafından sağlanan yatırımcı duyarlılığı endeksi, ikincisi yatırımc1 duyarlılığ 1 temsilcisi VIX Korku Endeksidir. Konferans Kurulu tarafindan hazırlanan Tüketici Güven Endeksi (CCI) ve sirasiyla Michigan Üniversitesi (MS) tüketici duyarlılığı endeksini ise ek ölçütler olarak ele almışlardır. Sonuçlar incelendiğinde öncelikle, yatırımcı duyarlılığının önemli olduğu ve hisse senedi fiyatlarının yükselmesinde ciddi bir rol oynadığı, duyarlılık odaklı yatırımcıların var olduğu görülmüştür.

Fettahoğlu (2017) yatırımc1 duyarlılı̆̆ bilgilerin pay senedi fiyatı üzerindeki birleşik etkisini incelemiştir. Çalışma BİST Kocaeli Şehir Endeksi'nde 2009-2015 yılları arasında kesintisiz olarak yer alan 13 adet işletme üzerinde regresyon ve ANOVA analizleri kullanılarak yapılmıştır. Sonuçta gelir beklentilerindeki artış pay senedi fiyatının artmasına neden olduğu ve yüksek duyarlılı̆̆ın yüksek indirgeme oranı anlamına geldiği belirtilmişti. Ayrıca yatırımcı duyarlılığının yüksek olmasının yatırımcının iyimser olduğunu gösterdiği yorumu yapılmıştır.

Debata vd. (2018) yerel ve yabancı yatırımcı duyarlılığının gelişmekte olan 12 ülkenin borsa likiditesine etkisini incelemişlerdir. Örnekleme dönemi Nisan 2002 'den Mart 2015' e kadar olan dönemdir. Piyasadaki duyarlılık-likidite ilişkisini incelemek için oluşturulan zaman serisi verileri, MSCI Gelişmekte olan Piyasa Endeksi ve S\&P Asia-50 Endeksi kullanılarak elde edilmiştir. ABD ve Avrupa Pazarları yatırımc1 duyarlılı̆̆1 temsilcisi olarak, Baker ve Wurgler duyarlılık endeksi ve Euro Bölgesi Duyarlılık Yatırımc1 Güven Endeksi kullanılmıştır. Toplam yükselen piyasa duyarlığı endeksi, 12 ülkenin ortogonal tüketici güven endeksi verisinin üçüncü ana bileşeni kullanılarak oluşturulmuştur. Makro değişkenler olarak enflasyon, sanayi üretim endeksi, büyüme oranı ve vade dağılımı alınmıştır. Sonuçlar incelendiğinde yabancı yatırımcı duyarlılığının gelişmekte olan borsa likiditesini önemli ölçüde etkilediği görülmüştür.

Kaya (2018) yatırımc duyarlılığı ile hisse senedi getirileri arasındaki ilişkiyi analize tabi tutmuştur. Verileri Haziran 1997-Eylül 2018 tarihinde aylık frekansta kullanmıştır. Öncelikle yatırımcı duyarlılığını temsil edebileceği varsayımı altında beş değişkenden yararlanarak, temel bileşenler analizi yöntemiyle duyarlılık endeksi hesaplanmıştır. Duyarlılık ile hisse senedi getirileri arasındaki ilişki regresyon analiziyle belirlenmiştir. Bulgularda yatırımcı duyarlılı̆̆ının hisse senedi getirilerini pozitif yönde etkilediği açıklanmıştır.

Akkuş ve Zeren (2019) Ocak 2011-Ağustos 2018 döneminde Türkiye' de yatırımcı duyarlılığını yansıtan Tüketici Güven Endeksi ile Katılım-30 İslami Hisse Senedi Endeksi arasındaki ilişkiyi incelemişlerdir. Analizde Hatemi J- Irandosut saklı eşbütünleşme testi ve Hatemi $\mathrm{J}$ asimetrik nedensellik testi kullanılmıştır. Bulgularda, Katılım-30 Endeksi ile Tüketici Güven Endeksi arasında nedensellikle karşılaşılmamıştır. Diğer yandan eşbütünleşme analizi sonucuna göre pozitif 
Yatırımcı Duyarlılığının Hisse Senedi Getirilerindeki Rolü ve Tüketici Güven Endeksiyle Ölçülmesi

şokların bahsedilen endeksler üzerinde, uzun dönem için entegre bir yapıya sahip olduğu görülmüştür.

\section{Uygulama}

Çalışmanın bu bölümünde İlk olarak araştırmanın önemi, amacı, hipotezleri, örneklemi, veri seti, değişkenleri ve yöntemi ile ilgili ayrıntılı bilgi verilmiştir. Daha sonra BİST' de yatırımcı duyarlılığı değişkeni ile anlamlı tahminler yapılabileceği hipotezinin geçerli olup olmadığı test edilmiştir. Son olarak yatırımcı duyarlılığının hisse senedi getirileri üzerindeki etkisi, kullanılan yöntem ve veriler ele alınarak incelenmiş ve ulaşılan bulgular yorumlanmıştır.

\section{A. Araştırmanin Amacı}

Çalışmada yatırımcıların beklentilerinde meydana gelen değişikliklerin belirlenmesi ve doğru kararlar almaları amacıyla, yatırımcı duyarlılı̆̆ının hisse senedi getirileri üzerindeki etkisi Türkiye piyasaları için tahmin edilmeye çalışılmıştır. Sınırlı olan literatürden yola çıkılarak, Türkiye için kullanılabilecek yatırımcı duyarlılığı değişkenleri, temsilcileri ve hisse senedi getirileri arasındaki ilişkinin tahmin edilmesi hedeflenmiştir. Çalışma ile, Türkiye' de yatırımcı duyarlılığı ve BISTT 100 Getiri Endeksi arasındaki ilişkinin tahmin edilmesi noktasında, literatüre katkı sağlaması beklenmektedir.

Çalışmanın Borsa İstanbul' da yatırım yapan ve rasyonel olmayan yatırımcıların davranışları üzerinde, yatırımcı duyarlılı̆̆ının etkisini ortaya koyması amaçlanmıştır. Ayrıca çalışmanın çeşitli finansal kuruluşlarda çalışan fon yöneticilerine de 1 șık tutacağına inanılmaktadır.

\section{B.Araştırmanın Hipotezleri}

$\mathrm{Bu}$ çalışmada yatırımcı duyarlılığı ve hisse senedi getirileri arasındaki ilişki ampirik olarak tahmin edilmiștir. "Türkiye finans piyasasında yatırımcı duyarlılığı, BİST 100 Getiri Endeksini tahmin edebilmekte midir?' sorusuna cevap aranmıștır.

DVM kullanılarak veri alanına yüklenen eğitim verileriyle oluşturulmuş modelin nasıl sonuç vereceğini ölçmek, tahmin ve gerçekleşen değerlerin karşılaştırılmasıyla mümkündür. Araştırmada kullanılan hipotezleri test etmek için dolaylı değişkenlere 5 model test edilmiştir. Modellere eklenen her bir değişken ile bağımlı değişkende meydana gelen değişim gözlemlenmiştir. Çalışmada kullanılan 5 modelin her biri için elde edilen tahminler ile gerçek veriler arasındaki ilişki açıklanmıştır. Bunun için çalışmadaki tüm modellerde 44 veriden oluşan gözlem verileri ile modellerden elde edilen tahminler, SPSS paket programina yüklenmiştir.

Buna göre oluşturulan hipotezler aşağıda verilmiştir:

$K_{0}$ : Gerçekleşen değerler ile modelden ulaşılan tahmin değerleri arasında anlamlı bir fark yoktur.

$E_{1}$ : Gerçekleşen değerler ile modelden ulaşılan tahmin değerleri arasında anlamlı bir fark vardır. 


\section{C.Çalışmanın Örneklemi ve Veri Seti}

Çalışmada kullanılan verilere TÜIKK ve Borsa İstanbul veri tabanlarından ulaşılmıştır. Başlangıç yılı tüm değişkenlerin veri setine ulaşalabilen 2007 y1lı Ocak ay1 olarak belirlenmiştir. 2007 Ocak - 2018 Aralık döneminin örneklem olarak dikkate alınmış ve aylık bazda toplam 144 gözlem değeri kullanılmıştır.

Analizde Borsa İstanbul' da piyasa endeksini belirtmek için kullanılan ve temel endeks olan BIST 100 getiri Endeksi bağımlı değişken olarak yer almaktadır. Borsanın genel performansını gösteren BIST 100 Getiri Endeksi, yatırımcılar tarafından takip edilen popüler endeksler arasında kabul edilmektedir. BIST 100 Getiri Endeksi, borsada yaşanan olumlu ve olumsuz gelişmeleri tüm yatırımcılara kısa süre içerisinde yansıtmaktadır.

Yatırımcı duyarlılığını ölçmede kullanılan ve yatırımcı duyarlılığını temsil eden değişkenler Tüketici Güven Endeksleri ve Tüketici Güven Endeksinin alt endeksleridir. Makroekonomik göstergelerden olan Tüketici Fiyat Endeksi (Enflasyon) ise, yatırımcı duyarlılığı değişkenlerinin tahmin başarısını ölçmek için kontrol değişkeni olarak ele alınmıştır.

\section{Araştırmanin Yöntemi}

Çalışmanın teorik kısmını destekleyecek olan yöntem Destek Vektör Makinesi (DVM)'dir. Yöntemi uygulamak için Statistica paket programından faydalanılmıştır.

Aşağıda istatistiksel öğrenmeye dayanan destek vektör makinelerinin genel özellikleri ile ilgili bilgiler verilmektedir.

\section{D.1. Destek Vektör Makineleri}

Destek Vektör algoritması altmışlı yıllarda Rusya'da geliştirilen Genelleștirilmiș Portre algoritmasının doğrusal olmayan bir genellemesidir. Bu nedenle, Vapnik ve Chervonenkis (1974) ve Vapnik (1982, 1995) tarafindan geliştirilen istatistiksel öğrenme teorisi ya da VC teorisi çerçevesinde sağlam bir şekilde temellenmiştir. VC teorisi, görünmeyen verileri iyi bir şekilde genellemelerini sağlayan öğrenme makinelerinin özelliklerini karakterize etmektedir. Mevcut haliyle, Destek vektör makineleri büyük ölçüde Vapnik ve iş arkadaşları tarafından AT\&T Bell Laboratuvarlarında geliştirilmiştir. Bu endüstriyel bağlamdan dolayı, destek vektör araştırmaları gerçek dünyadaki uygulamalara doğru sağlam bir yönelimde bulunmaktadır. İlk çalışma optik karakter tanımaya odaklanmaktadır. Kısa bir süre içerisinde, destek vektör sınıflandırıcıları hem optik karar tanıma hem de nesne tanıma görevleri için mevcut en iyi sistemlerle rekabet edebilmiştir. Destek vektör sınıflandırıcıları hakkında kapsamlı bir eğitim Burges (1998) tarafından yayınlanmıştır. Regresyon ve zaman serisi tahmin uygulamalarında kısa sürede mükemmel performanslar elde edilmiştir (Smola ve Schölkopf, 2004: 199-200).

Destek vektör makinesi (SVM), istatistiksel öğrenme teorisine dayanan evrensel bir yapıcı öğrenme prosedürüdür (Vapnik 1995). "Evrensel” terimi, destek vektör makinelerinin sinir ağları, radyal temel işlevleri, spline'lar, polinom tahmin 
edicileri gibi çeşitli gösterimleri öğrenmek için kullanılabileceği anlamına gelmektedir. Daha genel bir anlamda, destek vektör makineleri, fonksiyonlara yeni bir parametreleştirme şekli sağlamakta ve bu nedenle, düşünsüz öğrenme formülasyonları için ve dış tahminde öğrenme için de uygulanabilmektedir. Destek vektör makineleri parametrelemesi, fonksiyonun karmaşıklığı (destek vektörlerinin sayısı) sorununun boyutluluğundan bağımsız olarak anlamlı bir karakterizasyonunu sağlamaktadır (Cherkassky ve Mulier, 2007: 404-405).

Temel olarak, destek vektör makinesi bazı avantajlı özelliklere sahip doğrusal bir makinedir. Nasıl çalıştığını açıklamak için, belki de desen sınıflandırması bağlamında ortaya çıkabilecek ayrılabilir modeller söz konusu olduğunda başlamak en kolay yoldur. Bu bağlamda, bir destek vektörü makinesinin ana fikri, karar yüzeyi olarak pozitif ve negatif örnekler arasındaki ayrılma marjını maksimize edecek şekilde bir hiper düzlem inşa etmektir. Makine bu istenen özelliğe, istatistiksel öğrenme teorisine dayanan ilkeli bir yaklaşımı izleyerek ulaşmaktadır. Daha kesin olarak, destek vektörü makinesi yapısal risk azaltma yönteminin yaklaşık bir uygulamasıdır. Bu tümevarım prensibi, bir öğrenme makinesinin test verileri üzerindeki hata oranının, eğitim hata oranının toplamı ve Vapnik-Chervonenkis (VC) boyutuna bağlı bir terim tarafından sınırlandırılması gerçeğine dayanmaktadır. Ayrılabilir modellerde, bir destek vektörü makinesi birinci terim için sıfır değeri üretmekte ve ikinci terim en aza indirmektedir. Buna göre, destek vektörü makinesi, problem-alan bilgisini içermemesine rağmen model sinıflandırma problemlerinde iyi bir genelleme performansı sağlayabilir. Bu özellik, vektör makinelerini desteklemek için benzersizdir (Haykin, 2001: 340).

\section{D.2. Destek Vektör Makineleri İçin Model Başarı Kriterleri}

Tahmin modellerinin başarısını tanımlamak için literatürde farklı başarı ölçütleri öne sürülmüştür. Bu çalışmada kullanılan modellerin başarısını ölçmek amaciyla, Kök Ortalama Karesel Hata (KOKH), Nash-Sutcliffe Model Verimlilik Katsayısı (NSE) ve Ortalama Mutlak Hata (OMH) kriterleri ele alınmıştır. Söz konusu denklemler aşağıda belirtilmiştir.

$$
\begin{aligned}
& K O K H=\sqrt{\frac{1}{n} \sum_{i=1}^{n}\left(B_{\mathrm{p} i}-B_{o t}\right)^{2}}
\end{aligned}
$$

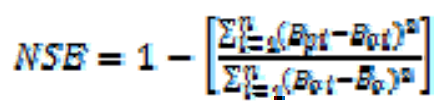

$$
\begin{aligned}
& O M H=\frac{1}{n} \sum_{i=1}^{n}\left|B_{o t}-B_{p t}\right|
\end{aligned}
$$

Denklemlerde yer alan ifadelerden $n$ gözlem sayısını, $B_{p i}$ tahminde bulunulmuş BIST 100 değerini, $B_{o i}$ gözlemlenen BIST 100 değerini, $B_{o}$ gözlemlenen BIST 100 değerlerinin ortalamasını ifade etmektedir. KOKH ve OMH 
denklemlerinin değeri 0 ile sonsuz arasındadır. Değerler sıfıra yaklaştıkça modelin başarısı artmakta, sıfır olduğunda ise modelden yüzde yüz başarı elde edildiği kabul edilmektedir. NSE ise hata karelerinin ortalaması ve gerçekleşen değerlerin varyansına bağlı olarak değişmektedir. Hata karelerinin ortalamasının gerçekleşen değerlerin varyansına oranının birden çıkarılması ile elde edilmektedir. NSE değeri eksi sonsuz ile 1 arasında değiş̧ebilen değerler almaktadır. NSE' inin 1 olması modelden yüzde yüz başarı elde edildiğini ifade etmektedir. NSE değerinin 0.85-1 arasında olması tahmin başarısının mükemmel olduğunu belirtmektedir (Başakın vd., 2019: 758-759).

\section{Bulgular ve Yorumlar}

$\mathrm{Bu}$ bölümde, değişkenleri içeren tanımlayıcı istatistiklere, hisse senedi getirilerini tahmin etmek için kullanılan yatırımcı duyarlılı̆̆ değişkenleriyle yapılan destek vektör makineleri analizine yer verilmiştir.

Çalışma kapsamında yatırımcı duyarlılığını ölçen temsilciler aracılığıyla hisse senedi piyasasının tahmini, destek vektör makineleri yöntemleri ile modellenmiştir. İlk olarak verilerin 100 adeti ile eğitim, geriye kalan 44 adeti model test edilmiş̧ir. Her iki yöntemde aynı oranda eğitilmiş ve test edilmiştir.

\section{A.Tanımlayıcı Ístatistikler}

Araştırmada yer alan değişkenlere ait tanımlayıcı istatistikler Tablo 1'de gösterilmiştir. Tablo 1 her biri 144 gözlem sayısından oluşan değişkenlerin sınıflandırılmasına uygun bir şekilde özet istatistiki bilgilerle düzenlenmiştir.

Tablo 1. Değişkenlere Ait Tanımlayıcı İstatistikler

\begin{tabular}{|l|l|l|l|l|l|l|}
\hline Değişkenler & Ortalama & $\begin{array}{l}\text { En } \\
\text { Büyük } \\
\text { Değer }\end{array}$ & $\begin{array}{l}\text { En } \\
\text { Küçük } \\
\text { Değer }\end{array}$ & $\begin{array}{l}\text { Standart } \\
\text { Sapma }\end{array}$ & $\begin{array}{l}\text { Çarpıklık } \\
\text { Katsayısı }\end{array}$ & $\begin{array}{l}\text { Basıklık } \\
\text { Katsayısı }\end{array}$ \\
\hline $\begin{array}{l}\text { BIST 100 Getiri } \\
\text { Endeksi Değeri }\end{array}$ & 99026 & 188490 & 30780 & 37700 & 0.325 & -0.498 \\
\hline TüİK-TGE & 71.772 & 85.024 & 55.657 & 6.503 & -0.312 & -0.524 \\
\hline TüİK-HMDB & 90.198 & 99.233 & 73.499 & 4.754 & -0.900 & 1.146 \\
\hline TüİK-GED & 95.638 & 117.401 & 67.297 & 10.402 & -0.466 & -0.128 \\
\hline TüİK-IS & 77.429 & 96.063 & 60.907 & 9.815 & 0.230 & -1.171 \\
\hline TÜİK-TEI & 23.824 & 30.667 & 15.033 & 3.695 & -0.145 & -0.736 \\
\hline TÜFE & 226.270 & 401.27 & 135.84 & 65.705 & 0.673 & -0.294 \\
\hline
\end{tabular}

Tablo 1'de görüldüğü üzere, değişkenlere ilişkin istatistiki bilgiler farklılık göstermektedir. Bağımlı değişken olan BIST 100 Getiri Endeksinde değişimin ortalaması yaklaş1k 100000' dir. Maksimum ve minumum değerlerin birbirinden oldukça farklı olduğu görülmektedir. Basıklık katsayısı -0.5 civarında gerçekleştiğinden, dağılımın değişkenliği fazladır. 
Yatırımcı duyarlılığını direkt ölçen değişkenler incelendiğinde ise istatistiki yorumlar dolaylı değişkenlerle farklılık göstermektedir. TÜİK Tüketici Güven Endeksi (TÜİK-TGE)' nin maksimum değeri 85, minumum değeri 55 ve ortalaması ise 71' dir. Tüketici Güven Endeksinin dört alt endeksinden biri olan TÜIKK Hanenin Maddi Durum Beklentisi Endeksi (TÜİK-HMDB)' nin maksimum değeri 99, minumum değeri 73 ve ortalaması ise 90' dir. TÜIK-Genel Ekonomik Durum Beklentisi Endeksi (TÜİK-GED) ise TGE' nin alt endekslerinden en yüksek ortalamaya ve standart sapmaya sahip olanıdır. TÜİK-GED' nin maksimum değeri 117, minumum değeri ise 67' dir. TÜİK-İsssiz Sayısı Beklentisi Endeksi (TÜIK-IS)' nin ortalamas1 77 civarında olup, maksimum ve minumum gözlemleri sırasıyla 96 ve 60' dır. Alt endeksler arasında dağılımının değiş̧kenliği en fazla olan (TÜIK -IS)' dir. Alt endekslerden sonuncusu olan TÜİK Tasarruf Etme İhtimali Endeksi (TÜIK-TEİ) nin ortalaması 23' dür. Alt endeksler arasındaki en düşük ortalama, maksimum değer, minumum değer ve standart sapmaya sahiptir.

Kontrol değişkeni olarak kullanılan Tüketici Fiyat Endeksi (TÜFE), bağımsız değişkenler arasında en yüksek ortalama, maksimum değer, minumum değer ve standart sapmaya sahiptir. TÜFE için basıklığa bakıldığında, dağılımın değişkenliğinin fazla olduğu görülmektedir.

\section{B.Destek Vektör Makineleri (DVM) Sonuçları}

Öncelikli sinıflandırma yöntemleri arasında bulunan destek vektör makineleri, günümüzde nonparametrik regresyon modeli olarak kullanılmaktadır. Destek vektör makinelerinde kullanılan alansal karar sınırı, klasik regresyonda kullanılan doğrusal karar sınırına göre, esneklik açısından avantaj sağlamaktadır. $\mathrm{Bu}$ avantaj ile birlikte destek vektör makineleri girdi ve çıktılar arasında doğrusal olmayan ilişkiler kurabilmektedir. BIST 100 Getiri Endeksi tahmininde DVM uygulamaları, birçok istatistiksel hesaplama aracı bulunduran veri analiz programı STATISTICA ile ortaya koyulmuştur. Bu çalışmada DVM modellerine uygun $\mathrm{C}, \varepsilon$ ve $\gamma$ tercih edilmesi esnasında sıkıntısız bir biçimde sonuca ulaşmak için STATISTICA programı kullanılmıştır. Yöntem aracılığıyla ele alınan her bir model, hata payı en az seviyeye indirilene kadar denenerek, optimum değişken grubuna ulaşılmaya çalışılmıştır. Verileri zaman alanından kernel uzayına taşırken veri ile uyum gösteren ve daha az değişkene gereksinim duyan radyal tabanlı kernel fonksiyonundan faydalanılmıştır. DVM' nin uygulanması esnasında karşılaşılan en büyük problem, etkileşim halinde olan model parametrelerinin optimize edilmesinin vakit almasidır.

Destek vektör makineleri analizi ile TGE ve alt endeksleri ele alınıp ulaşılan bulgular aşağıda yer almaktadır. Model hatasını temsil eden HKO, verimlilik katsayısı NSE ve $\mathrm{R}^{2}$ değerleri verilmiştir.

Analizde değişkenlerin her biri tek başına BIST 100 Getiri Endeksiyle analiz edilmiş ve 5 adet model elde edilmiştir. Analizlerin başarı kriterlerine (NSE) göre sonuçları aşağıda Tablo 2' de gösterilmiş ve yorumlanmıştır. 
Tablo 2. Destek Vektör Makineleri (DVM) Model Başarı Değerleri

\begin{tabular}{|l|l|l|l|l|l|}
\hline Model & Girdi & Çוkt & HKO & NSE & $\mathbf{R}^{\mathbf{2}}$ \\
\hline Model 1 & TÜİK, TGE & BIST 100 Getiri & 143807011 & 0.89 & 0.89 \\
\hline Model 2 & TÜİK, GED & BIST 100 Getiri & 148729245 & 0.89 & 0.89 \\
\hline Model 3 & TÜİK, İS & BIST 100 Getiri & 184310637 & 0.86 & 0.86 \\
\hline Model 4 & TÜİK, HMDB & BIST 100 Getiri & 191157681 & 0.86 & 0.86 \\
\hline Model 5 & TÜİK, TĖ & BIST 100 Getiri & 197106293 & 0.85 & 0.85 \\
\hline
\end{tabular}

Tablo 2 incelendiğinde, kurulan modellerin NSE' lerinin \%85 ve üzeri olduğu ve yapılan tahminlerin başarılı sonuçlar verdiği görülmektedir. Modellerin grafikleri çizilerek görsel olarak da karşılaştırılmıştır. Modellere ait destek vektör makineleri (DVM) grafikleri aşağıdaki gibidir.

Grafik 1. Destek Vektör Makineleri (DVM) Model Dă̆ıllım Grafikleri
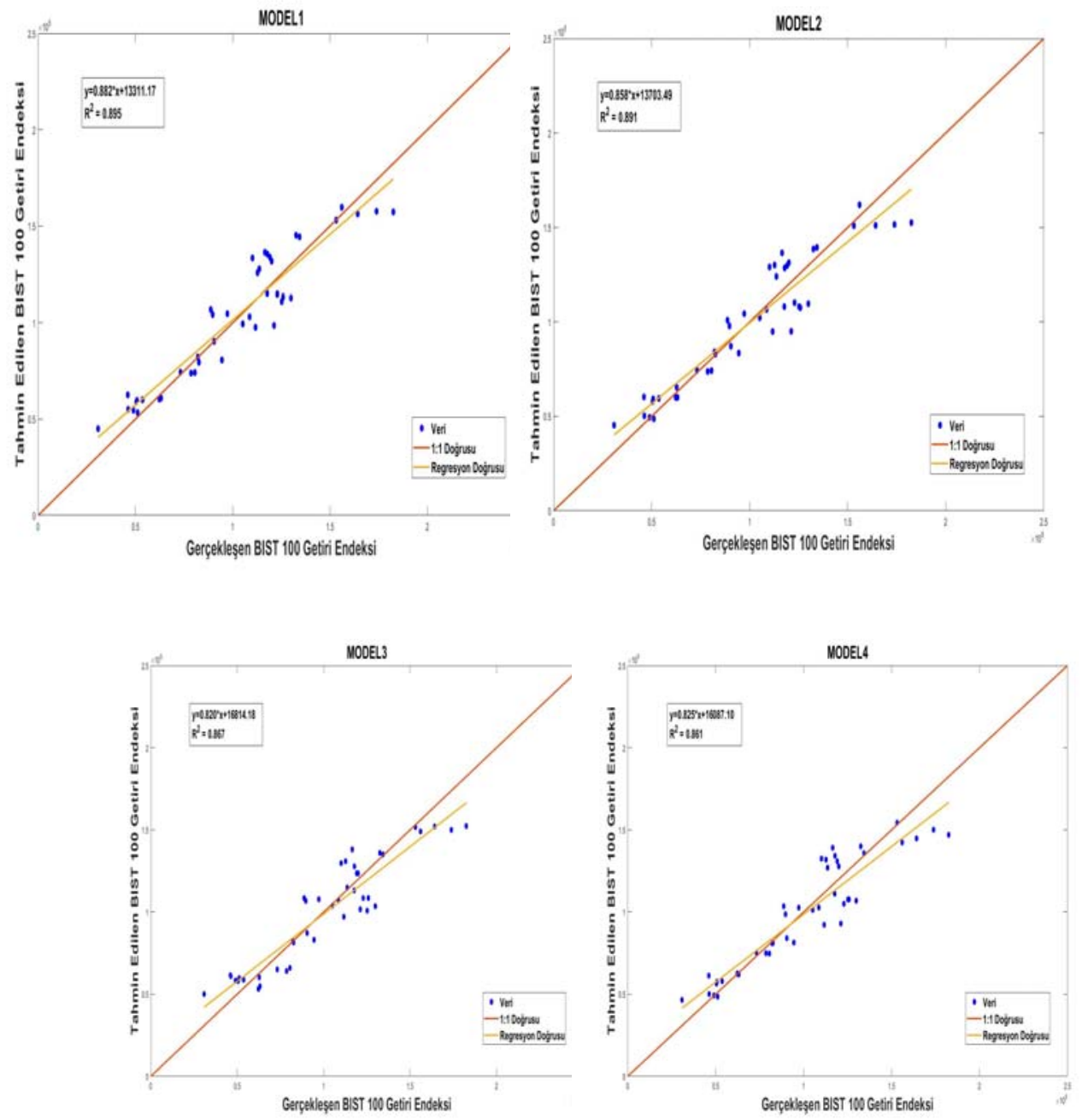


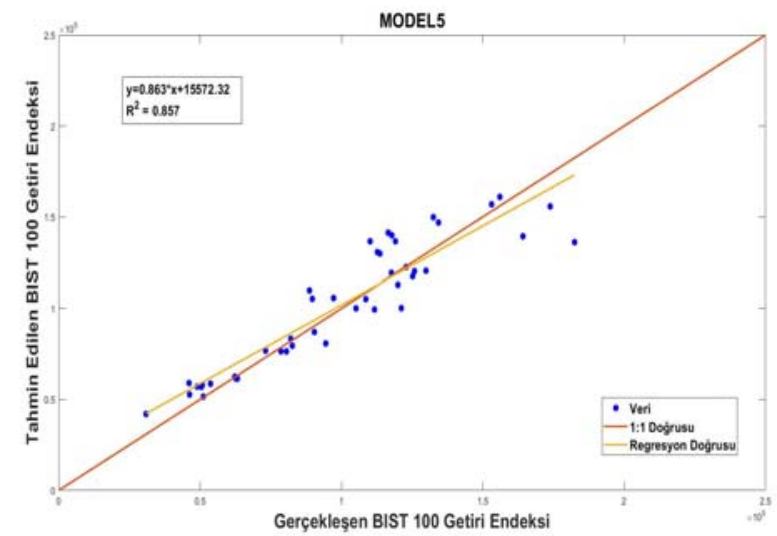

En iyi başarı kriterine sahip olan Model 1, Tüketici Güven Endeksinin BIST 100 Getiri Endeksini tahmini için kurulmuştur. Modelin HKO değeri 143807011, NSE değeri 0.89 ve $\mathrm{R}^{2}$ değeri 0.89 ' dur.

İkinci en iyi başarı kriterine sahip olan Model 2, Tüketici Güven Endeksinin alt endekslerinden olan Genel Ekonomik Durum Endeksinin BIST 100 Getiri Endeksini tahmini için kurulmuştur. Modelin HKO değeri 148729245, NSE değeri 0.89 ve $\mathrm{R}^{2}$ değeri 0.89 ’ dur.

Üçüncü en iyi başarı kriterine sahip olan Model 3, Tüketici Güven Endeksinin alt endekslerinden olan İșsiz Sayısı Endeksinin BIST 100 Getiri Endeksini tahmini için kurulmuştur. Modelin HKO değeri 184310637, NSE değeri 0.86 ve $\mathrm{R}^{2}$ değeri 0.86 ' dir.

Dördüncü en iyi başarı kriterine sahip olan Model 4, Tüketici Güven Endeksinin alt endekslerinden olan Hanenin Maddi Durum Beklentisi Endeksinin BIST 100 Getiri Endeksini tahmini için kurulmuştur. Modelin HKO değeri 191157681, NSE değeri 0.86 ve $\mathrm{R}^{2}$ değeri 0.86' dır.

Beşinci en iyi başarı kriterine sahip olan Model 5, Tüketici Güven Endeksinin alt endekslerinden olan Tasarruf Etme İhtimali Endeksinin BIST 100 Getiri Endeksini tahmini için kurulmuştur. Modelin HKO değeri 197106293, NSE değeri 0.85 ve $\mathrm{R}^{2}$ değeri $0.85^{\prime}$ dir.

Destek vektör makineleri (DVM) yönteminin açıklanmasının ardından, sonuçlar bölümünde tüm modellerin performanslarının kıyaslanmasına yer verilecektir.

\section{Hipotez Testi}

Hipotezlerin test edilmesi için $\mathrm{t}$ testi kullanılmıştır. Söz konusu testin çıktıları Tablo 3' de gösterilmektedir. 
Tablo 3. DVM Modelleri için Gerçekleşen Değer ile Tahmin Değerlerinin Karşılaştırılması

\begin{tabular}{|c|c|c|c|c|c|c|}
\hline Modeller & $\begin{array}{c}\text { Direkt } \\
\text { Değişkenlere } \\
\text { Ait } \\
\text { Modellerin } \\
\text { Değerleri } \\
\end{array}$ & Ortalama & $\mathbf{N}$ & $\begin{array}{l}\text { Standart } \\
\text { Sapma }\end{array}$ & t değeri & $\begin{array}{l}\text { p } \\
\text { değeri }\end{array}$ \\
\hline \multirow[t]{2}{*}{1} & Gerçekleşen & 99963.39 & 44 & 37158.94 & \multirow[t]{2}{*}{-0.204} & \multirow[t]{2}{*}{0.839} \\
\hline & Tahmin & 101524.92 & 44 & 34653.27 & & \\
\hline \multirow[t]{2}{*}{2} & Gerçekleşen & 99963.39 & 44 & 37158.94 & \multirow[t]{2}{*}{0.064} & \multirow[t]{2}{*}{0.949} \\
\hline & Tahmin & 99478.42 & 44 & 33775.22 & & \\
\hline \multirow[t]{2}{*}{3} & Gerçekleşen & 99963.39 & 44 & 37158.94 & \multirow[t]{2}{*}{0.158} & \multirow[t]{2}{*}{0.874} \\
\hline & Tahmin & 98780.68 & 44 & 32722.67 & & \\
\hline \multirow[t]{2}{*}{4} & Gerçekleşen & 99963.39 & 44 & 37158.94 & \multirow[t]{2}{*}{0.184} & \multirow[t]{2}{*}{0.855} \\
\hline & Tahmin & 98586.58 & 44 & 33045.35 & & \\
\hline \multirow[t]{2}{*}{5} & Gerçekleşen & 99963.39 & 44 & 37158.94 & \multirow[t]{2}{*}{-0.247} & \multirow[t]{2}{*}{0.806} \\
\hline & Tahmin & 101855.24 & 44 & 34653.72 & & \\
\hline
\end{tabular}

Tablo 3'de dolaylı değişkenler aracılığıyla oluşturulan DVM modellerinden başarı kriterlerine göre sıralanan ilk 10 model, direkt değişkenler aracılığıyla oluşturulan DVM modellerinden başarı kriterlerine göre sıralanan tüm modeller bulunmaktadır.

DVM modelleri için gerçekleşen değerler ile tahmin değerleri arasındaki $\mathrm{t}$ test değerleri ve p değerleri Tablo 3'de gösterilmektedir. Buna göre değişkenlerden oluşan modellerin $\mathrm{p}$ değerleri $0,05^{\prime}$ ' den büyük olduğundan gerçekleşen değerler ile tahmin değerleri arasında fark yoktur yorumu yapılabilir. Kurulan bu modellerle yapılan tahminler başarılıdır.

\section{Sonuç Ve Öneriler}

Yatırımcılar finansal piyasalarda işlem gören veya ilgi duydukları hisse senedi fiyatlarını etkileyen etkenler hakkında bilgi sahibi olmak ve hisse senedi getirileri için doğru tahminde bulunmak isterler. Hisse senedi getirilerinin tahmini, finansal aktörlerin tümünün üzerinde yoğunlaştığı konular arasında yer almaktadır. Dolayısıyla hisse senedi getirilerini tahmin etmeyi amaçlayan birçok teori ileri sürülmüştür. Söz konusu teorilerden birincisi, hisse senedi fiyatlarının rasyonel olarak belirlendiği varsayımına dayanan geleneksel finans teorisi, ikincisi ise hisse senedi fiyatlarının her zaman rasyonel olarak belirlenmediği ve psikolojik etkenlerinde dikkate alındığı varsayımına dayanan davranışsal finans teorisidir.

Kahneman ve Tversky (1979)' nin ileri sürdüğü beklenti teorisiyle ilk kez finans literatürüne giren davranışsal finans, yatırımcı psikolojisinin hisse senedi fiyatlarının oluşumunda önemli bir rol oynadığını ortaya koymaktadır. Davranışsal finansa göre yatırımcılar, sistematik bir şekilde psikolojik yanılgılar duymakta ve bu yanılgılardan dolayı yanlış kararlar verebilmektedirler. 
Beklenti teorisinin ardından yatırımcı davranışlarının finansal piyasalardaki etkisini araştıran üç temel teori geliştirilmiştir. Bunlar zihinsel muhasebe teorisi, sürü davranışı teorisi ve yatırımcı duyarlılığı teorisidir. Zihinsel muhasebe ve sürü davranışı ile ortaya çıkan duygusal eğilimler, sistematikleşerek fazladan bir risk kaynağı olabilmektedir. Ortaya çıkan riske ise yatırımcı duyarlılığının sebep olduğu kabul edilmektedir.

$\mathrm{Bu}$ çalışmada BIST 100 Getiri Endeksi yatırımcı duyarlılığı ile tahmin edilemeye çalışılmıştır. Yatırımcı duyarlılığını temsil eden Tüketici Güven Endeksi ve alt endeksleriyle tahmin modelleri kurulmuştur. 2007 Ocak -2018 Aralık dönemini kapsayan çalışmada BIST 100 Getiri Endeksi bağımlı değiş̧ken, yatırımcı duyarlılığını temsil eden Tüketici Güven Endeksi ve alt endeksleri ise bağımsız değişkenler olarak kullanılmıştır. Tahmin modelleri oluşturulurken verilerin \%70' i eğitim, \%30' u test için kullanılmıştır. Modellerin oluşturulması sırasında DVM yönteminden faydalanılmıştır. Bu yöntemin yatırımcı duyarlılığı teorisinde ilk kez kullanılmasının literatüre önemli bir fayda sağlayacağı düşünülmektedir.

Model başarı sonuçları HKO, NSE ve $\mathbb{E}^{2}$ parametreleri yardımıyla yorumlanmıştır. Kullanılan tahmin yöntemlerinin analiz performansları kıyaslandığında DVM yönteminin başarılı performans sergilediği dikkati çekmektedir.

Yatırımc1 duyarlılığ1 temsilcilerinden tüketici güven endeksi ve tüketici güven endeksinin alt endeksleri getiri tahminlemesi açısından uygun bulunmuştur. Literatür incelendiğinde çalışmayla uyumlu [Otoo (1999), Korkmaz ve Çevik (2009), Topuz (2011), Kale ve Akkaya (2016), Tekin ve Cengiz (2019)] olarak tüketici güven endeksinin hisse senedi piyasasının tahmininde etkin olduğunu gösteren sonuçlara ulaşıldığı görülmektedir.

Analiz sonuçlar incelendiğinde, yatırımcı duyarlılığının hisse senedi getirilerini tahmin etme konusunda başarılı olduğu görülmektedir. TÜIKK-TGE hisse senedi getirilerini önemli ölçüde tahmin edebilmektedir. Genel olarak bakıldığında, çalışmada yer alan tahmin güçleri farklı olsada, yatırımcı duyarlılığının BIST 100 Getiri Endeksini başarılı bir şekilde tahmin ettiği söylenebilmektedir.

Bu sonuçlardan yola çıkarak, yatırımcı duyarlılığını dikkate alan hisse senedi yatırımcılarının daha başarılı sonuçlar elde etmesi beklenmektedir. Çünkü finansal piyasalarda işlemler her zaman rasyonel beklentilere göre yapılmamakta, söylenti unsuruda göz önünde bulundurulmaktadır. Söylenti unsuruda yatırımcı duyarlılı̆̆ 1 izlenerek hesaba katılmaktadır. Söylenti unsurunun dikkate alınmasıda yatırımcıların daha etkin olmasını sağlamaktadır.

Yatırımcı duyarlılığı temsilcilerinden en doğru olanının seçilmesi ve getiri tahminlerinde kullanılmasının, bireysel ve kurumsal yatırımcıların yatırım kararlarına katkı sağlayacağı düşünülmektedir. Türkiye için, getiri tahmininde yatırımcı duyarlılığı temsilcilerinden Tüketici Güven Endeksinin alt endekslerinin 
incelendiği bir çalışmaya rastlanmamıştır. Bu konuda tezin literatüre katkıda bulunması hedeflenmektedir.

Gelecek çalışmalarda farklı değişkenler kullanılarak hisse senedi getirisi yatırımcı duyarlılığı ile tahmin edilebilir. Direkt değişkenlerden TÜİK Tüketici Güven Endeksi yerine CNBC-e/Bloomberg HT Güven Endeksi ve dolaylı değişkenler yerine farklı değişkenler kullanılarak analizler tekrarlanabilir.

\section{Kaynaklar}

Akhtar, Shumi; Faff, Robert; Oliver, Barry; Subrahmanyam, Avanidhar (2011). The power of bad: The negativity bias in Australian consumer sentiment announcements on stock returns. Journal of Banking \& Finance, 35(5), 1239-1249.

Akkuş, Hilmi T.; Zeren, Feyyaz (2019). Tüketici Güven Endeksi ve Katılım-30 İslami Hisse Senedi Endeksi Arasındaki Saklı İlişkinin Araştırılması: Türkiye Örneği. Third Sector Social Economic Review, 54(1), 53-70.

Antoniou, Constantinos.; Doukas, John A.; Subrahmanyam Avanidhar (2013). Cognitive dissonance, sentiment, and momentum. Journal of Financial and Quantitative Analysis, 48(1), 245-275.

Baker, Malcolm; Wurgler, Jeffrey (2006). Investor sentiment and the cross-section of stock returns. The journal of finance, 61(4), 1645-1680.

Başakın, Eyyup. E.; Özger, Mehmet; Ünal, Necati. E. (2019). Gri tahmin yöntemi ile İstanbul su tüketiminin modellenmesi. Politeknik Dergisi, 22(3), 755-761.

Bathia, Deven; Bredin, Don (2013). An examination of investor sentiment effect on G7 stock market returns. The European Journal of Finance, 19(9), 909-937.

Black, Fischer (1986). Noise. The journal of finance, 41(3), 528-543.

Charoenrook, Anchada (2005). Does sentiment matter. Unpublished working paper. Vanderbilt University.

Chau, Frankie; Deesomsak, Rataporn; Koutmos, Dimitrios (2016). Does investor sentiment really matter? International Review of Financial Analysis, 48, 221-232.

Cherkassky, Vladimir.; Mulier Filip (2007). Learning from data: concepts, theory, and methods. John Wiley \& Sons.

Coakley, Jerry; Dotsis, George; LIU, Xiaoquan; Zha1, Jia (2014). Investor sentiment and value and growth stock index options. The European Journal of Finance, 20(12), 1211-1229.

Corredor, Pilar; Ferrer, Elena; Santamaria, Rafael (2013). Investor sentiment effect in stock markets: Stock characteristics or country-specific factors?. International Review of Economics \& Finance, 27, 572-591.

Debata, Byomakesh; Dash, Saumya R.; Mahakud, Jitendra (2018). Investor sentiment and emerging stock market liquidity. Finance Research Letters, $26,15-31$. 
Yatırımcı Duyarlllığının Hisse Senedi Getirilerindeki Rolü ve Tüketici Güven Endeksiyle Ölçülmesi

De Long, J. Bradford; Shleifer, Andrei; Summers, Lawrance H.; Waldmann, Robert J. (1990). Noise trader risk in financial markets. Journal of political Economy, 98(4), 703-738.

Ergün, Zeliha C. (2019). Investor Sentiment Evidence from Borsa İstanbul. Ekin Yayınevi. Ankara.

Fernandes, Carla M. D. A.; Gonçalves, Paulo M. M. G.; Vıerı, Elisabete F. S. (2013). Does sentiment matter for stock market returns? Evidence from a small European market. Journal of Behavioral Finance, 14(4), 253-267.

Ferrer, Elena, Salaber, Julie; Zalewska, Anna (2016). Consumer confidence indices and stock markets' meltdowns. The European Journal of Finance, 22(3), 195220.

Fettahoğlu, Sibel (2017).Yatırımcı Duyarlılığının Pay Senedi Fiyatı Üzerindeki Etkisi: BIST'de bir Uygulama. Uluslararası İktisadi ve İdari İncelemeler Dergisi, 443-454.

Haykin, Simon (2001). Neural networks, a Comprehensive Foundation. Preditice Hall, Englewood Cliffs. New Jersey.

Kandır, Serkan. Y. (2006). Tüketici güveni ve hisse senedi getirileri ilişkisi: İMKB Mali sektör şirketleri üzerinde bir uygulama. Çukurova Üniversitesi Sosyal Bilimler Enstitüsü Dergisi, 15(2), 217-230.

Kahneman, Daniel; Tversky, Amos (1979). Prospect Theory: An Analysis of Decision Under Risk, Econometrica, 47(2), 263-292.

Kale, Süleyman; Akkaya, Murat (2016). The relation between confidence climate and stock returns: The case of Turkey. Procedia economics and finance, 38, $150-162$.

Kaya, Emine (2018). Yatırımcı Duyarlılığ1 ve Hisse Senedi Getirileri. Finans Politik \& Ekonomik Yorumlar, 55(645), 91-112.

Korkmaz, Turhan; Çevik, Emrah İ. (2009). Reel Kesim Güven Endeksi ile İMKB 100 Endeksi arasındaki dinamik nedensellik ilişkisi. Istanbul University Journal of the School of Business Administration, 38(1).

Lemmon Michael; Portniaguına, Evgenia (2006). Consumer confidence and asset prices: Some empirical evidence. The Review of Financial Studies, 19(4), 1499-1529.

Olgaç, Serkan; Temizel, Fatih (2008). Yatırımcı Duyarlılığı Hisse Senedi Getirileri İlişkisi:Türkiye Örneği. TISK Academy/TISK Akademi, 3(6).

Otoo, Maria. W. (1999). Consumer sentiment and the stock market.

Qiu, Lily.; Welch, Ivo (2004). Investor sentiment measures (No. w10794). National Bureau of Economic Research.

Schmeling, Maik (2009). Investor sentiment and stock returns: Some international evidence. Journal of empirical finance, 16(3), 394-408.

Shleıfer, Andrei (2000). Inefficient markets: An introduction to behavioural finance. OUP Oxford.

Smola, Alex J.; Scholkopf, Bernhard (2004). A tutorial on support vector regression. Statistics and computing, 14(3), 199-222. 
Tekin, Bilgehan; Cengiz, Selim (2019). Pay Senedi Piyasası ile Tüketici Güven Endeksi Arasındaki Nedensellik ve Eşbütünleşme İlişkileri (The Casuality and Cointegration Relationships Between Stock Market and Consumer Confidence Index: A Case Study in Borsa Istanbul). Tekin, B. \& Cengiz, S.(2018), Journal of Social And Humanities Sciences Research (JSHSR), 5, 29.

Topuz, Yusuf V. (2011). Tüketici güveni ve hisse senedi fiyatları arasındaki nedensellik ilişkisi: Türkiye örneği. Ekonomik ve Sosyal Araştırmalar Dergisi.

Vapnik, Vladimir N. (1995). The nature of statistical learning. Theory.

https://www.borsaistanbul.com

http://www.tuik.gov.tr 